\title{
Surveys of Viruliferous Alate Aphid of Plum pox virus in Prunus mume Orchards in Japan
}

Kota Kimura, NARO Agricultural Research Center, Kan-nondai, Tsukuba, Ibaraki 305-8666, Japan; and Department of Clinical Plant Science, Faculty of Bioscience and Applied Chemistry, Hosei University, Kajino-cho, Koganei, Tokyo 184-8584; Tomio Usugi, NARO Agricultural Research Center; Hideo Hoshi, Ayana Kato, Tsuyoshi Ono, and Shinji Koyano (deceased), Tokyo Metropolitan Agriculture and Forestry Research Center, Fujimi-cho, Tachikawa, Tokyo 190-0013; Satoshi Kagiwada and Takeshi Nishio, Department of Clinical Plant Science, Faculty of Bioscience and Applied Chemistry, Hosei University; and Shinya Tsuda, NARO Agricultural Research Center

\begin{abstract}
Kimura, K., Usugi, T., Hoshi, H., Kato, A., Ono, T., Koyano, S., Kagiwada, S., Nishio, T., and Tsuda, S. 2016. Surveys of viruliferous alate aphid of Plum pox virus in Prunus mume orchards in Japan. Plant Dis. 100:40-48.

Plum pox virus (PPV) is transmitted by infected buds and aphids. It is important to analyze the outbreak trends and viruliferous rate of aphids in areas where the occurrence of PPV is reported, so as to develop strategies for disease control. Between April 2011 and December 2012, yellow insect-trapping adhesive plates were placed for 2 days at a time each week in an area where PPV is occurring in Japan. Outbreak trends were analyzed based on the trapped alate aphid samples, and up to 50 of them were tested per week to identify species and determine the rate of viruliferous specimens. Although the number of aphids varied according to survey year, three peaks were noticeable in each year. Based on the sequence

data for the mitochondrial cytochrome c oxidase I region, approximately 40 different species of aphid were trapped in both years. Of the five dominant species of aphids identified during the 2 years, Aphis spiraecola was trapped in large numbers. PPV-positive aphids were higher in fall onward, when the total number of trapped aphids decreased, than in spring and summer, when a larger number of aphids was caught. PPV transmission tests using the most abundant species revealed that A. spiraecola, A. craccivora, A. gossypii, and Rhopalosiphum maidis were transmitters, although A. spiraecola is likely of epidemiological significance.
\end{abstract}

Blossoms of the Japanese apricot (Prunus mume Sieb. et Zucc) have been admired since ancient times in Japan and its fruit has been processed into umeboshi (salted apricot) or umeshu (apricot wine), making the tree commercially highly valuable. However, an outbreak of Plum pox virus (PPV) in Tokyo (Maejima et al. 2010 ) could potentially pose a serious threat to $P$. mume production in Japan.

PPV was confirmed for the first time in Bulgarian plum in 1915 (Atanasoff 1932). Since then, it has spread across nearly the entire region of Europe during the 1970s (Llacer and Cambra 1998; Roy and Smith 1994); coastal areas of the Mediterranean, including Egypt and Syria in the 1980s (Cambra et al. 2004; Kaya et al. 2014; Mazyad et al. 1992); and to India, China, Chile, and North America in the 1990s (Reyes et al. 2003; Rosales et al. 1998).

In accordance with the Plant Protection Act, PPV is designated as a pest subject to quarantine in Japan and caution is exercised to prevent invasion. The first case of a PPV (D strain) was confirmed in April 2009 on a plum tree in Ome City, Tokyo (Maejima et al. 2010). Since then, the infection on plum trees has rapidly spread throughout Japan and; in 2013, 11,593 infected trees were newly found in eight prefectures. In Ome City, which is famous for its Japanese apricot blossom viewing and where PPV was first detected in Japan, more than 26,000 plum trees have been cut down thus far to prevent the further spread of PPV. The areas where PPV infection was confirmed in 2013 included the Kansai region, which accounts for a dominant share of the domestic P. mume yields, and its potential negative

Corresponding author: S. Tsuda; E-mail: shinyat@affrc.go.jp

The nucleotide sequence data for the mitochondrial cytochrome $\mathrm{c}$ oxidase I gene from Myzus mumecola reported in this study appear in DDBJ, EMBL, and GenBank nucleotide sequence databases with the following accession numbers: B738877.1 and AB738876.1

Accepted for publication 29 June 2015

http://dx.doi.org/10.1094/PDIS-05-15-0540-RE

(C) 2016 The American Phytopathological Society impacts on the industry and tourism are of major concern (Tsuda and Sano 2014)

PPV belongs to the genus Potyvirus in the family Potyviridae. Virions form filamentous particle, 660 to $770 \mathrm{~nm}$ in length and 12.5 to $20 \mathrm{~nm}$ in width. The virus comprises a positive-sense, single-stranded RNA genome, coding a P1 protein with a proteolytic activity, with a molecular mass of approximately $35 \mathrm{kDa}$; a helper-component proteinase (HC-Pro) involving aphid transmission, with a molecular mass of approximately $52 \mathrm{kDa}$; a $\mathrm{P} 3$ protein relating to symptom development, with a molecular mass of approximately $50 \mathrm{kDa}$; a cylindrical inclusion protein found in the cytoplasm, with a molecular mass of approximately $71 \mathrm{kDa}$; a viral genome-linked protein, with a molecular mass of approximately $21 \mathrm{kDa}$; an NIa-Pro with serine-like cysteine protease, with a molecular mass of approximately $27 \mathrm{kDa}$; an NIb with the RNA-dependent RNA polymerase activity, with a molecular mass of approximately $58 \mathrm{kDa}$; a coat protein, with a molecular mass of approximately $30 \mathrm{kDa}$; and three small open reading frames (ORF) of a pretty interesting potyvirus $\mathrm{ORF}, 6 \mathrm{~K} 1$, and a $6 \mathrm{~K} 2$, respectively (Fauquet et al. 2005). PPV is categorized into eight strains (D, M, Rec, C, CR, W, EA, and T) according to serological and molecular characteristics (Glasa et al. 2013), among which D, M, and Rec are the major strains worldwide. The D strain was first isolated from $P$. armeniaca in southern France and is spreading worldwide, including in the United States, Canada, and China. The M strain was isolated from $P$. persica in Greece and has been confirmed in many locations throughout Europe. In addition, the $M$ strain has been reported to be more efficiently transmitted via aphid vectors than the D strain (Dallot et al. 1998). The Rec strain was isolated from P. domestica in Slovakia and results from recombination of the $\mathrm{D}$ and $\mathrm{M}$ strains (Glasa et al. 2002).

PPV is transmitted by grafting, sap, or insects but is not transmitted via seed. With the exception of dissemination through the use of symptomless infected budwood, the most prominent mode of transmission under natural conditions is insect transmission. PPV can be transmitted by more than 20 different types of aphids (Goytia et al. 2006). Aphids that have acquired PPV can transmit it only within a timeframe of approximately $10 \mathrm{~min}$ into a few hours. This is because PPV has a noncirculative, nonpersistent transmission pattern whereby 
the virus can be transmitted only while the tip of the stylets of the aphid is in contact with the virus (Fereres and Moreno 2009). It is generally believed that noncirculative viruses can be carried by various types of aphid nonselectively and that any aphid can acquire the virus from the sap of an infected plant. However, the transmission efficiency of potyviruses depends on the affinity between the HC-Pro of the virus and the stylet of the aphid; hence establishing carrier specificity (Wang et al. 1998).

It would not be easy to detect plant viruses in its insect vectors compared with infected plant materials such as leaves and branches, because the insect body is so small and the amount of virus is very low. Nevertheless, a few feasible detecting techniques for PPV in the aphid vectors using polymerase chain reaction (PCR)-based assays have been previously described (Cambra et al. 2004; Olmos et al. 1999, 2005; Wetzel et al. 1992). The methods suitable for an epidemiological investigation to handle many insect vector samples are not developed well enough to sufficiently maintain the level of high sensitivity for PPV detection.

The primary purpose of this study was to identify aphid species that transmit PPV in Japan and obtain information to be used to develop management measures. First, we trapped alate aphids in areas infested with PPV on a continuous basis and identified different species based on nucleotide sequence data to determine dominant aphid species and their outbreak patterns. Second, we tested each of the identified samples for the virus to ascertain high-risk aphid species that may transmit PPV in the infected areas, developing a new detection method for PPV in the vector aphids based on the nested PCR technique. Third, we tested transmissibility of the aphid species that were suspected to be the major vectors in the areas.

\section{Materials and Methods}

Aphid collection. Surveys to investigate annual fluctuations in the number of aphids in local orchards were conducted from April to December 2011 and from April to December 2012 in (i) a P. mume orchard in an area with a high density of PPV (D strain) occurrence in Ome City, Tokyo (hereinafter referred to as high-density area [HDA]) and (ii) a P. mume orchard in an area of Tokyo where existence of trees infected with PPV has yet to be surveyed (nonsurveyed area [NSA]). One set of four yellow insect-trapping adhesive plates was prepared so that they are facing in four different directions at each locations at a height of approximately $70 \mathrm{~cm}$ to attract alate aphids. All trapped aphid individuals were counted. Yellow sticky plates were set up every week for a period of 2 days, and the collected aphids were stored at $-80^{\circ} \mathrm{C}$.

Insecticides were applied as conventional maintenance procedures of cultivation in HDA. Flonicamid wettable powder was sprayed on 14 May 2011 and dinotefuran granulated wettable powder on 30 May 2011, whereas acetamiprid wettable powder was sprayed on 14 to 16 April 2012, flonicamid wettable powder on 19 to 21 May 2012, and dinotefuran granulated wettable powder on 1 to 4 June 2012. In contrast, no insecticide was used in NSA.

Nucleic acid extraction. From each survey area, 50 aphids (maximum) were collected from the adhesive sheets, and each aphid was individually placed in a $2-\mathrm{ml}$ bead-beating tube with two $0.2-\mathrm{cm}$ zirconia beads. A 200- $\mu$ l aliquot of TRIzol Reagent (Life Technologies, Carlsbad, CA) and $75 \mu$ l of chloroform were added and shredded in a multibead shocker (Yasui Kiki, Osaka, Japan). Two cycles were performed under the following conditions: oscillation frequency, 2,500 rpm; shredding time, $60 \mathrm{~s}$; rest time, $10 \mathrm{~s}$. Thereafter, the contents were centrifuged for $15 \mathrm{~min}$ at $15,000 \mathrm{rpm}$ and $4^{\circ} \mathrm{C}$. A $100-\mu \mathrm{l}$ aliquot of the resulting aqueous layer was transferred to a new $1.5-\mathrm{ml}$ microtube, and $75 \mu \mathrm{l}$ of 2-propanol and $1 \mu \mathrm{l}$ of glycogen were added. After being stirred gently, the solution was centrifuged for $15 \mathrm{~min}$ at $15,000 \mathrm{rpm}$ and $4^{\circ} \mathrm{C}$. The supernatant was decanted, and $300 \mu \mathrm{l}$ of $70 \%$ ethanol was added to the pellet. The solution was lightly stirred and then centrifuged for $15 \mathrm{~min}$ at $15,000 \mathrm{rpm}$ and $4^{\circ} \mathrm{C}$. The supernatant was decanted and, after complete desiccation in a centrifugal drier, the extract was dissolved in $10 \mu \mathrm{l}$ of sterile distilled water. Specimens prepared as above were subjected to the following two detection systems separately for aphids and the virus.
Amplification and purification of aphid DNA by PCR. Following the TaKaRa Ex Taq protocol (Takara Bio, Shiga, Japan), $0.5 \mu$ l of nucleic acid extract, $1.5 \mu \mathrm{l}$ of dNTP, $2 \mu$ l of $10 \times$ Ex Taq buffer, $0.1 \mu \mathrm{l}$ of Ex Taq, $1 \mu \mathrm{l}$ of each primer $(5 \mu \mathrm{M} / \mu \mathrm{l})$, and doubledistilled water (DDW) at the end were added to prepare $20 \mu \mathrm{l}$ of the PCR solution. The primer set used comprised LCO1490 (5'-GGTCAACAAATCATAAAGATATTGG-3') and HCO2198 (5'-TAAACTTCAGGGTGACCAAAAAATCA-3') to amplify $658 \mathrm{bp}$ of the mitochondrial cytochrome c oxidase I gene region, which enables identification of aphids down to the species level (Folmer et al. 1994). PCR was performed using the following program: $94^{\circ} \mathrm{C}$ for $5 \mathrm{~min} ; 5$ cycles of $94^{\circ} \mathrm{C}$ for $1 \mathrm{~min}, 45^{\circ} \mathrm{C}$ for $90 \mathrm{~s}$, and $72^{\circ} \mathrm{C}$ for $90 \mathrm{~s} ; 35$ cycles of $94^{\circ} \mathrm{C}$ for $1 \mathrm{~min}, 50^{\circ} \mathrm{C}$ for $90 \mathrm{~s}$, and $72^{\circ} \mathrm{C}$ for $1 \mathrm{~min}$; and $72^{\circ} \mathrm{C}$ for $5 \mathrm{~min}$ (Hebert et al. 2003). After the reaction, $4 \mu \mathrm{l}$ of the PCR product was diluted in $36 \mu \mathrm{l}$ of DDW, and electrophoresis was performed using LabChip GX (Perkin-Elmer, Waltham, MA) to verify the presence of bands. DNA was purified by mixing $2 \mu l$ of $0.1 \times$ ExoSAP-IT (Affymetrix, Santa Clara, CA) with $5 \mu$ l of the PCR solution, using a program setting of $37^{\circ} \mathrm{C}$ for $30 \mathrm{~min}$ followed by $80^{\circ} \mathrm{C}$ for $15 \mathrm{~min}$.

Sequence reaction and nucleotide sequence analysis. An aliquot of the sequencing reaction solution was prepared to a final volume of $10 \mu l$ using a BigDye Terminator v1.1 Cycle Sequencing Kit (Life Technologies) from $0.5 \mu$ l of purified DNA, $1 \mu$ l of BigDye Terminator v1.1, $1.5 \mu \mathrm{l}$ of $5 \times$ sequencing buffer, $1 \mu \mathrm{l}$ of each primer (LCO1490 and HCO2198, $0.8 \mu \mathrm{M} / \mu \mathrm{l}$ ), and DDW at the end. The sequencing reaction was performed using a program setting of $96^{\circ} \mathrm{C}$ for $1 \mathrm{~min}$ followed by 25 cycles of $96^{\circ} \mathrm{C}$ for $10 \mathrm{~s}, 50^{\circ} \mathrm{C}$ for $5 \mathrm{~s}$, and $60^{\circ} \mathrm{C}$ for $4 \mathrm{~min}$. The reaction products were purified using a Dye Terminator Removal Kit (Thermo Scientific, Waltham, MA); they were completely dried in a centrifugal drier and then dissolved in $10 \mu \mathrm{l}$ of Hi-Di formamide (Life Technologies). A sample plate was set in the tray of 3130 Genetic Analyzer (Life Technologies) and sequencing was performed. The nucleotide sequence analysis was performed with CodonCode Aligner (Codon Code Corporation, Centerville, MA), and species were identified by National Center for Biotechnology Information BLAST database searches. The criterion adopted for species identification was that $0.2 \%$ or less discrepancy in nucleotide sequences against a reference species recorded in the database was considered to be the same (Foottit et al. 2008).

Aphid sampling and nucleic acid extraction for PPV detection. Virus screening was conducted for 50 aphids collected from the adhesive sheets from each of the sites to identify the aphid species. The negative control area for virus screening was set in Tsukuba City, Ibaraki Prefecture, which is approximately $100 \mathrm{~km}$ away from the PPV outbreak zone in Tokyo. Five aphids per week (maximum) were collected from the yellow adhesive plates installed in this area and surveyed in the same manner.

Virus detection in one aphid using nested reversetranscription PCR. The reverse-transcription (RT)-PCR detection system for PPV in the vector aphids was newly developed for this study. The methods previously published (Olmos et al. 1999, 2005) seemed to be not suitable for an epidemiological investigation to handle many insect vector samples sufficiently, even if those would maintain the level of high sensitivity for PPV detection. Primary RT-PCR was performed using a PrimeScript One Step RTPCR Kit (ver. 2; Takara Bio) in a test solution consisting of $2 \mu l$ of nucleic acid extract, $5 \mu l$ of $2 \times 1$-step buffer, $0.4 \mu l$ of PrimeScript 1 step Enzyme Mix, and $0.4 \mu \mathrm{l}$ of each $5 \mu \mathrm{M}$ primer, to which RNase-free water was added up to $10 \mu \mathrm{l}$ in total volume. New designed primers PPV nest P1 (5'-CAGCCTGAATTTACAT TGTCCATGG-3') and PPV nest R1 (5'-CATCAACTTCCTCCT CGTCTTCTC-3') were used to amplify $1,000 \mathrm{bp}$ of the NIb gene region, allowing the amplification of all D strains of PPV stored as nucleotide sequence databases in DDBJ, EMBL, and GenBank. PCR was performed using a program setting of $50^{\circ} \mathrm{C}$ for $30 \mathrm{~min}$; $94^{\circ} \mathrm{C}$ for $2 \mathrm{~min}$; and 35 cycles of $94^{\circ} \mathrm{C}$ for $20 \mathrm{~s}, 60^{\circ} \mathrm{C}$ for $10 \mathrm{~s}$, and $72^{\circ} \mathrm{C}$ for $1 \mathrm{~min}$. cDNA obtained was diluted $1: 10$ and subjected to secondary PCR. 
Nested PCR was performed with KOD dash (TOYOBO, Osaka, Japan) after mixing $1 \mu \mathrm{l}$ of cDNA that had been diluted by a factor of 10 with DDW, $1 \mu l$ of $10 \times$ buffer, $1 \mu l$ of $10 \mathrm{mM}$ dNTPs, $0.1 \mu \mathrm{l}$ of KOD Dash, and $0.2 \mu \mathrm{l}$ of each $5 \mu \mathrm{M}$ primer, to which DDW was added to make up $10 \mu$ l of test solution. The primer set used comprised the newly designed PPV P4 (5'-TGCAGTTCTCAA TATTCGTCTGGC-3') and PPV nest R2 (5'-TCCAAGTTGG GAAAA-3'), producing 346 bp of the cDNA fragment from the NIb gene region amplified in the first round. PCR was performed under the following conditions: $94^{\circ} \mathrm{C}$ for $2 \mathrm{~min} ; 35$ cycles of $94^{\circ} \mathrm{C}$ for $20 \mathrm{~s}, 60^{\circ} \mathrm{C}$ for $10 \mathrm{~s}$, and $72^{\circ} \mathrm{C}$ for $20 \mathrm{~s}$; and $4^{\circ} \mathrm{C}$ to stop the reactions. Finally, $4 \mu \mathrm{l}$ of the resulting PCR product was diluted 1:10, and electrophoresis was performed using LabChip GX (Perkin-Elmer) to verify the presence of bands.

Statistical analysis. Using month, year, and the survey areas as explanatory variables, we applied logistic regression analysis according to the formula presented below to analyze the relationships between the explanatory variables and the incidence of PPV-positive insects, which was estimated from the number of PPV-positive insects surveyed in the study fields, as well as the reliability of that correlation.

$$
\begin{aligned}
\ln \left(\frac{p}{1-p}\right) & =k+a \cdot \text { month }+b \cdot \text { area }+c \cdot \text { year }+d \cdot \text { month } * \text { area } \\
& +e \cdot \text { month } * \text { year }+f \cdot \text { area } * \text { year }+g \cdot \text { month } * \text { area } * \text { year }+\varepsilon
\end{aligned}
$$

Although sampling was conducted weekly in this survey, weekly changes were unsuitable as the explanatory variables for statistical processing due to the considerably low stability of the model; therefore, weekly data were combined to afford an explanatory variable on a monthly basis. Posthoc tests were performed using a G-test with Bonferroni-Holm correction to compare monthly variability. The statistical analysis was performed using JMP (ver. 5.1.2; SAS Institute Inc., Cary, NC).

PPV transmissibility evaluation. Seven different species of aphids (Aphis craccivora, A. gossypii, A. spiraecola, Melanaphis sacchari, Rhopalosiphum maidis, Myzus mumecola, and M. persicae) were captured live in Tsukuba City, Ibaraki Prefecture and maintained in a greenhouse at $27^{\circ} \mathrm{C}$ on host plant seedlings appropriate to each aphid species. Specimens were prepared to identify species based on conventional exterior morphology.

Live aphids maintained in the greenhouse were transferred to a plastic container using a thin paint brush and fasted for $1 \mathrm{~h}$. Ten fasted apteran aphids were next placed on a $P$. mume leaf infected with PPV, and they were allowed to access acquisition feeding for $1 \mathrm{~min}$ after the aphids left on the leaf didn't move any more. The aphids were then transferred to a healthy $P$. mume seedling about $10 \mathrm{~cm}$ in height and allowed to access inoculation feeding overnight. The next day, the aphids were eradicated using an insecticide, and the inoculated $P$. mume plants were checked after 1 month to determine whether or not transmission had occurred based on the presence or absence of disease symptoms and the results of a serum test using Plum pox immune-chromato (Nippon Gene, Tokyo).

\section{Results}

Aphid outbreak trends in the surveyed areas. The number of aphids trapped on the yellow adhesive plates during the survey period in 2011 was 1,165 in HDA and 2,687 in NSA. The seasonal outbreak trends as illustrated in line graphs revealed that the number peaked in both areas during late April to late May, early June to late June, and late July to early September (Fig. 1). Another peak occurred in late November in NSA (Fig. 1b). The number of aphids trapped in 2012 was substantially lower than that in 2011, with 631 trapped in HDA (54.2\% year-on-year) and 950 trapped in NSA (35.4\% year-on-year) (Fig. 2). Due to the smaller sample size, no clear trapping peak was seen from the data calculated based on weekly collections. However, seasonal variation trends in the number of trapped aphids were the same as those observed in the previous year, with many outbreaks evident during parts of the spring, summer, and fall.
Dominant aphid species in the survey areas. Nucleotide sequence analysis was performed on 3,267 aphids trapped on the yellow adhesive plates during the survey period. In all, 45 aphid species were identified in HDA, 48 species in NSA, and 64 species in total from the two sites combined. Of those species identified, 13 species were known to transmit PPV (data not shown). The species accounting for $\geq 2 \%$ of the total number of samples for which sequence analysis was performed were selected as dominant species (Wallis et al. 2005). Outbreak trends for these dominant species by survey year and survey area are described below.

Year 2011. In total, 888 aphids were identified in HDA. Their seasonal trends revealed that A. craccivora, A. gossypii, A. spiraecola, and Tinocallis zelkowae were the four dominant species during May and June, when the number of aphids trapped on the adhesive boards increased. A. gossypii, A. spiraecola, Melanaphis sacchari, and $R$. maidis were the four dominant species trapped in August, when the second highest number of aphids was trapped. Phorodon humuli was prominent beginning in November and A. spiraecola was trapped throughout the year (Fig. 1a).

In total, 982 aphids were identified in NSA. Major fluctuations were observed in the number of aphids trapped on the adhesive boards and there was a clear segregation between different species according to trapping peaks. Whereas A. gossypii and A. spiraecola were dominant in late April and May, they were clearly replaced by A. craccivora and T. zelkowae in June. In addition to these four species that occurred in the spring, M. sacchari and Shivaphis celti were also dominant in late July and August. A diverse range of aphids occurred in November, including A. gossypii and A. spiraecola (Fig. 1b).

Year 2012. In total, 588 aphids were identified in HDA. When compared with the figures from 2011, no clear peaks were observed in 2012 in the numbers of aphids trapped, with minor peaks in June, September through early October, and November. A. craccivora, A. gossypii, A. spiraecola, and Hyalopterous pruni were the four dominant species in June, whereas A. spiraecola was almost exclusively found from September to early October. A. gossypii, $P$. humuli, $R$. padi, and $R$. rufiabdominalis were dominant in November. A. spiraecola was trapped throughout the season in 2012, similar to the trend in 2011 (Fig. 2a).

In total, 809 aphids were identified in NSA. No clear peaks were observed in the number of aphids trapped, similar to the pattern observed in HDA in the same year. After sporadic occurrences in midJune, aphids continued to occur at a moderate level between early August and early December. A. spiraecola was dominant in midJune, whereas A. gossypii, Lipaphis pseudobrassicae, and S. celti were the three dominant species from early August through September. These species were replaced by $A$. spiraecola and $P$. humuli from October to early December (Fig. 2b).

When the results of the surveys from both years were taken as a whole, it was clear that there was a major difference in the occurrence patterns for dominant aphid species in the surveyed areas. Despite there was being at least seven dominant species in HDA in 2011 (Fig. 1a), A. spiraecola accounted for the vast majority in 2012 (Fig. 2a). Similarly, in NSA, various aphid species occurred at trapping peaks in 2011 (Fig. 1b) but a limited number of species, such as A. spiraecola and S. celti, were found in 2012 (Fig. 2b). On the other hand, similar trends were observed between HDA and NSA with regard to the seasonal trends in dominant aphid species during each year of the survey. In 2011, A. craccivora, A. gossypii, A. spiraecola, and $T$. zelkowae were common in both areas as dominant species in the spring, whereas A. gossypii, A. spiraecola, and M. sacchari were common in the summer; $A$. spiraecola was continuously dominant beginning September in both areas (Fig. 1). Likewise, in 2012, $P$. humuli was dominant both in HDA and NSA in November and later in the year, and A. spiraecola was trapped throughout the year in both locations, although the dominant species were different between the two areas only between early August and September (Fig. 2).

Based on nucleotide sequence analysis, 12 aphid species were identified as dominant in this study (Table 1). Of these, the following five species accounted for $\geq 2 \%$ of the total in both HDA and NSA in both 2011 and 2012: A. spiraecola, A. gossypii, A. craccivora, 
$R$. rufiabdominalis, and $H$. pruni. The other seven species accounted for $<2 \%$ in either one of the survey areas or one of the survey years. Among the dominant species, A. spiraecola and A. gossypii showed the least change year-to-year and showed a dominance ratio of $10 \%$ or more in both areas and in both years. The species trapped most frequently during the survey period was $A$. spiraecola, which accounted for approximately $26 \%$ (845 aphids) of the total.

Virus-positive aphid rate in the survey areas. The 3,276 samples for which nucleotide sequence analysis was performed were tested for the presence of PPV. Of all the samples, 126 tested positive (55 individuals in HAD and 71 in NSA), sharing $25 \%$ in HAD and $31 \%$ in NSA of A. spiraecola as highest infectious species among the positive aphids, followed by T. zelkowae in HAD and A. gossypii in NSA (Fig. 3). In contrast, all 352 samples from Tsukuba City, which was set up as a negative control area, tested negative for the virus during the survey period. For viruses such as PPV transmitted in a nonpersistent manner, the risk of disease spread increases with the number of flying alate aphids that are possibly able to transmit the virus in an area including contaminated orchards. From the perspective of formulating prevention and eradication measures, it is important to investigate the periods and locations in which the risk of PPV transmission by aphids is high.
In this study, statistical analysis was conducted to discern factors that contributed to the increase in the number of virus-infected samples using "survey area", "survey year", and "survey month" as main effects. In addition to the aforementioned main effects, interactions produced between two or three of these factors were also examined. Furthermore, because data from the months of April to December in both the survey years were insufficient in the aphid sample size to form a population, which could compromise the reliability of the statistical tests, they were excluded from the analysis. Under these statistical conditions, the effects of survey month and tertiary interaction within a combination of survey area-survey year-survey month were significant when survey month was the only factor $(P<0.0001)$ and also when a tertiary interaction was taken into account $(P=0.0359)$; thus, significant differences were acknowledged in these two patterns (Table 2). A significant difference in the effect of survey month suggests that the appearance of virus-infected samples differed from month to month.

In our first attempt of statistical analysis, effects of interactions were rather difficult to interpret. Therefore, based on our judgment that it would be more straightforward to summarize data by year to explain interaction effects, we performed statistical analyses again for the 2011 and 2012 survey results separately. As a consequence,

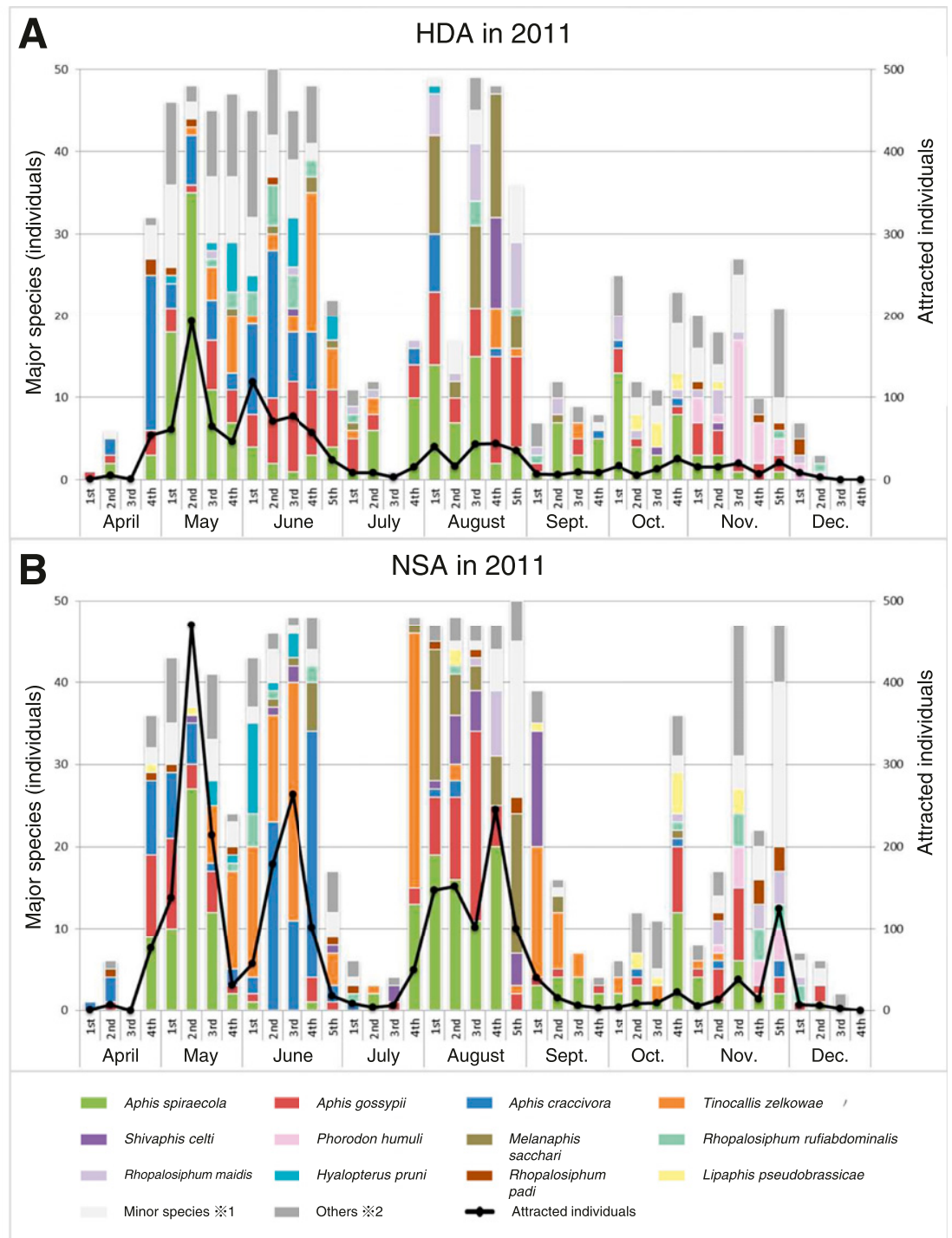

Fig. 1. Outbreak trends for dominant aphid species in 2011 in the survey areas. A, Plum pox virus (PPV) high-density occurrence area (HDA). B, PPV nonsurveyed area (NSA). Bar graph, number of dominant aphids identified (left axis); line graph, number of aphids trapped on yellow adhesive boards (right axis). Minor species = aphid species accounting for $<2 \%$ of the total number. Others = samples with no hits in a BLAST search and samples that could not be identified due to $a \geq 0.2 \%$ difference from the nucleotide sequences in database. 
the only significant difference of the effect of month was shown in 2011 (Table 3,P=0.0032). No significant difference was detected for survey area or for the interaction of survey area-survey month. Similarly, for 2012, a significant difference of survey month only was observed, whereas the interaction effect between the location and the survey date was at an insignificant level (Table $4, P=$ 0.0012).

No significant difference was detected between the two survey areas for each year; therefore, we decided to treat the difference between the two areas as negligible. We summed the number of aphids that tested virus positive in both areas for each year and calculated the monthly virus-positive insect rate by considering only the survey month. The results showed that the virus-positive insect rate for May to September 2011 was not significantly different at a range of 0.9 to $2.0 \%$, but it increased to $8.1 \%$ in October and then decreased to $3.4 \%$ in November. This means that the virus-positive insect rate is significantly higher in the early to late fall (when the total number of trapped aphids was lower) than that during the spring or summer period (when the number of trapped aphids was higher) (Fig. 4a). In 2012, no significant difference was seen in the virus-positive rate between May and August at 1.4 and $1.6 \%$, respectively; on the other hand, it was significantly higher at over $5.2 \%$ in June, July, and
September through November. This was particularly the case in October, when the virus-positive rate was significantly high at $12.7 \%$ (Fig. 4b). A comparison of the calculated virus-positivity rates between 2011 and 2012 showed that, although results are different in terms of percentages, both years shared the same occurrence patterns for virus-positive insects. These survey results clearly indicate that virus-positive insect rates fluctuate mainly according to the season.

Evaluation of PPV transmissibility. We compared the transmissibility of PPV by 5 of the 12 dominant species of aphids that were trapped (A. craccivora, A. gossypii, A. spiraecola, M sacchari, and $R$. maidis), as well as Myzus mumecola and M. persicae, from infected to healthy P. mume (Table 5). The species with the highest transmission rate was $M$. persicae at $24.4 \%$. A spiraecola had the second highest transmission rate $(13.1 \%)$. Transmission rates for A. craccivora and A. gossypii were relatively low (5.3 and $3.7 \%$, respectively). Transmissibility was not detected for Melanaphis sacchari. It is noteworthy that PPV transmissibility was shown for the first time for Myzus mumecola and R. maidis in this study. Infection transmitted by M. mumecola was identified in 5 of 41 plants (12.2\%), showing a certain level of transmissibility. Infection by $R$. maidis was also found in 1 of 29 plants $(3.4 \%)$.

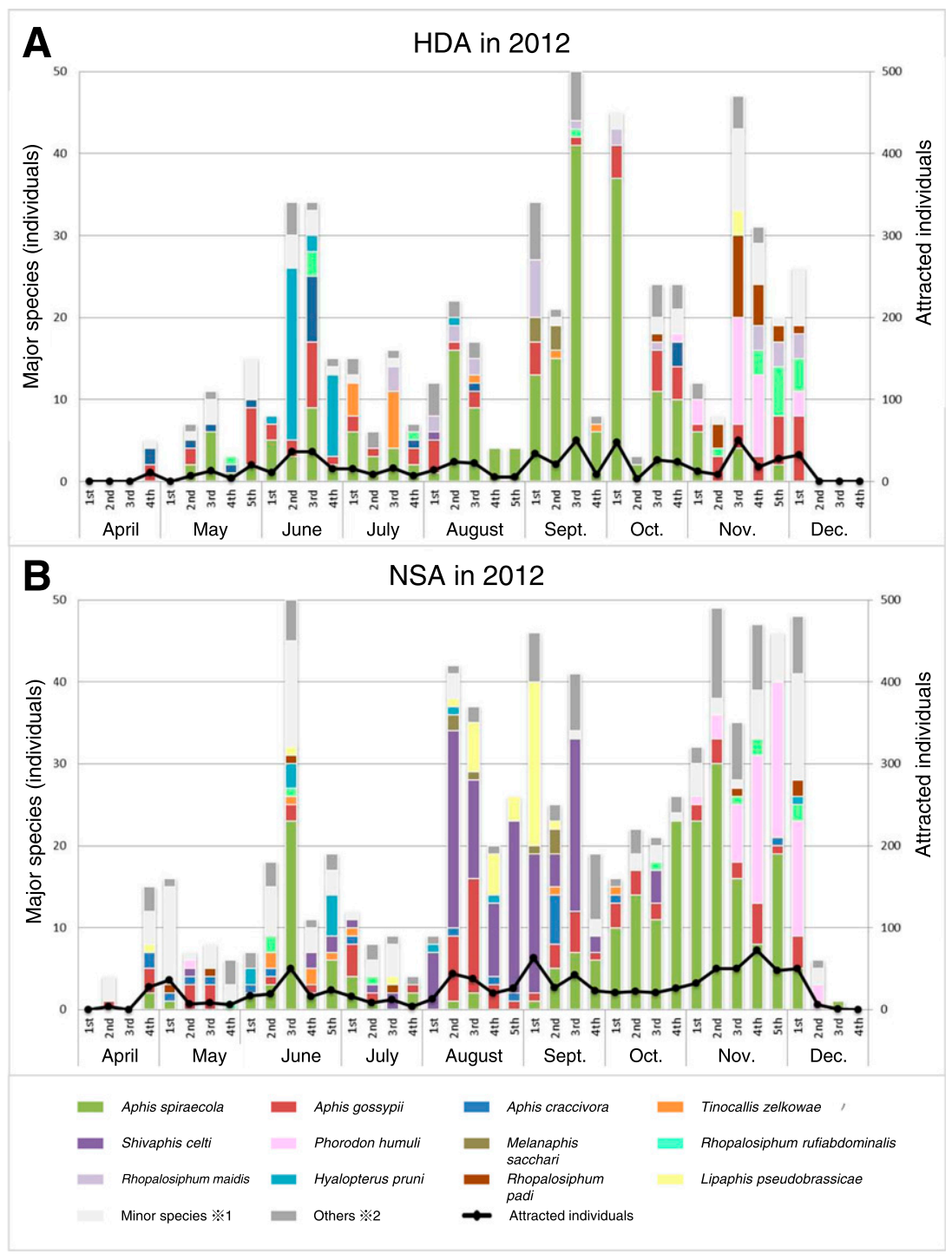

Fig. 2. Outbreak trends for dominant aphid species in 2012 in the survey areas. A, Plum pox virus (PPV) high-density occurrence area (HDA). B, PPV nonsurveyed area (NSA). Bar graph, number of dominant aphids identified (left axis); line graph, number of aphids trapped on yellow adhesive boards (right axis). Minor species = aphid species accounting for $<2 \%$ of the total number. Others $=$ samples with no hits in a BLAST search and samples that could not be identified due to a $\geq 0.2 \%$ difference from the nucleotide sequences in database. 


\section{Discussion}

In terms of the 2011 aphid occurrence fluctuation pattern, trapping peaks were observed in the spring, summer, and parts of the fall. However, based on the results of virus detection tests and statistical analyses, the period with the highest virus-positive insect rate was the fall, including October at $8.1 \%$ and November at $3.4 \%$, which was not understood for some reason. The average temperature during this period of the year rose to about $31^{\circ} \mathrm{C}$ in the summer from $12^{\circ} \mathrm{C}$ in the spring, and descended to about $17^{\circ} \mathrm{C}$ from summer to autumn, according to an official record of the Japan Meteorological Agency. These results suggest that, rather than spring and summer, when the number of trapped aphids is relatively high, fall is the period with the greatest risk of PPV outbreaks, when the rate of virus-positive insects is increased. In fall 2011, A. gossypii, A. spiraecola, and $P$. humuli were shown to be dominant species. At that time, the species that were found with high numbers of virus-positive insects were A. fukii, A. gossypii, A. spiraecola, and T. zelkowae. Two species with major occurrence in the fall, A. gossypii and A. spiraecola, were among those virus-positive insects.

Although the 2012 aphid occurrence pattern was unclear, trapping peaks were observed in the spring, summer, and fall. The change of average temperature this year was about $12^{\circ} \mathrm{C}$ in the spring to $33^{\circ} \mathrm{C}$ in the summer and descended to about $15^{\circ} \mathrm{C}$ in autumn, the same as above. Based on the results of virus detection tests and statistical analysis, in addition to the period of September through November, when the virus-positive insect rate ranged from 6.1 to $12.7 \%$, periods other than the fall season also demonstrated relatively high viruspositive rates, including the months of June at $6.6 \%$ and July at $5.2 \%$. Therefore, the PPV transmission risk was likely to be high among aphids occurring during June, July, and fall 2012. In June and July, A. spiraecola and H. pruni were dominant whereas, in the fall, A. gossypii, A. spiraecola, and P. humuli were dominant. Species that were actually high in the number of virus-positive insects were A. gossypii, A. spiraecola, $P$. humuli, and $H$. pruni; thus, the composition of aphid species occurring in the fall exactly matched that of species with a high number of virus-positive insects. This was particularly the case with A. gossypii and A. spiraecola, which both occurred during the fall for two consecutive years.

PPV infections in Japan are similar to epidemiology in the Mediterranean Sea area. It has previously been described that the proportions of aphid species captured in the Prunus salicina orchards in the Valencia region, Spain in 3 years $(1993,2002$, and 2003) were A. spiraecola (43\%), A. gossypii (18\%), H. pruni (6\%), Brachycaudus prunicola (6\%), A. craccivora (3\%), M. persicae (2\%), and other species (22\%); and the percentage of virus-positive aphids was $11.9 \%$ in May (Cambra et al. 2004). In the Antakya-Hatay region of Turkey, the dominant aphid species were A. spiraecola and A. gossypii, showing a peak in May in both 2011 and 2012; and the percentages of PPV-viruliferous aphids were $12.5 \%$ in A. spiraecola, $12.42 \%$ in A. gossypii, and $11.11 \%$ in H. pruni (Kaya et al. 2014). Based on the fact that the virus-positive insect rate for the both $A$. spiraecola and A. gossypii was high, they are likely to pose a high PPV transmission risk. In previous studies aimed at detecting PPV in aphids, it is known that the virus could be detected in nonvector species (Olmos et al. 1999, 2005). Therefore, aphids may carry the virus in their intestinal tract after having fed on a PPV-infected tree without being a vector of PPV. However, the detection of PPV in flying aphids is a very important indication that active sources of PPV are present in or around the area, meaning a high risk of spreading PPV disease in cases where PPV-positive aphids, particularly A. spiraecola and $A$. gossypii, were detected in the area.

Although $M$. persicae demonstrated a relatively high PPV transmission rate of $22.4 \%$ in experimental transmission tests, a rate of $63 \%$ has been reported in cases of peach-to-peach transmission using the same PPV-D strain (Gildow et al. 2004). The transmission efficiency observed with $M$. persicae in this study was lower compared with the results from overseas. The transmission rate for A. spiraecola was $13.1 \%$ and it was the second highest after $M$. persicae in our study. On the other hand, A. gossypii has been reported as an inefficient vector based on results from experiments conducted in North America and Europe (Labonne et al. 1995), and this study also showed a low rate of $3.7 \%$. Meanwhile, the PPV transmissibility was newly confirmed for $M$. mumecola and $R$. maidis. M. mumecola is known to be parasitic on $P$. mume and occurs in large numbers during the period of foliation in March through April. In this study, only 14 individuals of this species were trapped and none tested positive for PPV. However, because the species showed the second highest rate of transmission efficiency after A. spiraecola at $12.2 \%$ in the transmission test, we recognize the need for more detailed surveys of its behavior in early spring and the occurrence patterns of its alate form. Although $R$. maidis was found to be a dominant species in this study, it is believed to be an inefficient vector because it had a relatively low transmission rate of $3.4 \%$ in the tests. In the case of Melanaphis sacchari, the presence of virus-positive aphids was verified but it did not transmit PPV experimentally. The vector specificity of Potyvirus spp., including PPV, has been known, likely because viral particles are unable to attach to the tip of stylets of certain aphid species, which is a required process for transmission (Uzest et al. 2007). It was evident that $M$. sacchari was sucking sap from PPV-infected plants but its PPV transmissibility was not verified; thus, it was considered not to be an insect vector at this point.

It was suspected that $A$. gossypii contributed to the PPV transmission in the affected areas based on the results of the 2-year field survey and PPV transmission tests showing that the species occurred in large numbers during the fall, a large number of virus-positive insects were detected, and it was proven experimentally that it transmitted PPV. However, because its PPV transmission efficiency was relatively low, it was surmised that it was not the main vector species. In contrast, A. spiraecola occurred in large numbers in the fall, during which the PPV transmission risk was high, and it also showed a relatively high transmission efficiency of $13.1 \%$ in PPV transmission tests. These results suggest that $A$. spiraecola could be among main aphid species contributing to PPV transmission in HDA in Tokyo. The virus detection tests revealed many virus-positive insects among A. fukii, T. zelkowae, H. pruni, and Phorodon humuli. However, because nested RT-PCR is an extremely sensitive method, it is important to note that the PPV transmission may not necessarily follow just because virus-positive results are obtained. Because PPV is a nonpersistent, noncirculating type of virus, it loses its capability to be passed on within $1 \mathrm{~h}$ of being acquired by an aphid. In contrast, it is possible to detect PPV from artificially created viruliferous insects $24 \mathrm{~h}$ after they become carriers. In other words, aphids that have lost the ability

Table 1. Dominant aphid species in two survey areas during a 2-year survey period $^{\mathrm{a}}$

\begin{tabular}{|c|c|c|c|c|c|c|}
\hline \multirow[b]{2}{*}{ Species } & \multicolumn{2}{|c|}{ HDA } & \multicolumn{2}{|c|}{ NSA } & \multicolumn{2}{|c|}{$\begin{array}{l}\text { Total of both } \\
\text { areas }\end{array}$} \\
\hline & 2011 & 2012 & 2011 & 2012 & $N$ & Percent \\
\hline Aphis spiraecola ${ }^{\mathrm{b}}$ & 201 & 226 & 190 & 228 & 845 & 26 \\
\hline A. gossypii ${ }^{\mathrm{b}}$ & 129 & 78 & 118 & 81 & 406 & 12 \\
\hline A. craccivora $^{\text {b }}$ & 92 & 19 & 106 & 19 & 236 & 7 \\
\hline Tinocallis zelkowae & 50 & 14 & 148 & 9 & 221 & 7 \\
\hline Shivaphis celti & 14 & 1 & 37 & 130 & 182 & 5 \\
\hline Phorodon humuli ${ }^{\mathrm{b}}$ & 29 & 30 & 13 & 66 & 138 & 4 \\
\hline Melanaphis sacchari & 50 & 6 & 59 & 7 & 122 & 4 \\
\hline Rhopalosiphum rufiabdominalis & 25 & 20 & 24 & 31 & 100 & 3 \\
\hline R. maidis ${ }^{\mathrm{b}}$ & 41 & 29 & 21 & 0 & 91 & 3 \\
\hline Hyalopterus pruni ${ }^{\mathrm{b}}$ & 20 & 35 & 19 & 14 & 88 & 3 \\
\hline R. padi & 10 & 22 & 17 & 18 & 67 & 2 \\
\hline Lipaphis pseudobrassicae & 8 & 3 & 16 & 39 & 66 & 2 \\
\hline Minor species ${ }^{c}$ & 97 & 52 & 97 & 72 & 318 & 10 \\
\hline Others $^{\mathrm{d}}$ & 122 & 53 & 117 & 95 & 387 & 12 \\
\hline Total & 888 & 588 & 982 & 809 & 3267 & 100 \\
\hline
\end{tabular}

${ }^{\text {a }} \mathrm{HDA}=$ high-density area and NDA = nonsurveyed area.

b Species of aphids reported as Plum pox virus vectors.

${ }^{c}$ Species accounting for $<2 \%$ of the total number of aphids captured in both areas.

d Species with no hits in a BLAST search. 
to transmit PPV as well as aphids that have acquired the virus but are not capable of transmitting it, such as $M$. sacchari, can be detected as virus-positive insects with nested RT-PCR, and not all virus-positive insects are necessarily confirmed as PPV carriers. Thus, it is essential to perform separate PPV transmission tests to verify the capability and efficiency of transmission for these four aphid species.

Furthermore, almost no Myzus persicae aphids, the main PPV transmitter overseas, were trapped in this study. This result suggests that there is difference among aphid species in terms of the level of their attraction to yellow adhesive plates. When yellow versus green water traps are set to trap A. spiraecola, aphids are known to be attracted to the yellow traps in three times higher numbers compared with those attracted to the green traps (Avinent et al. 1991). Although A. spiraecola was attracted in the highest numbers in our present study, it is conceivable that each aphid species shows a varied level of affinity toward the yellow adhesive plates, and new studies using other survey methods, such as water traps, are needed. Actually, a certain number of $M$. persicae individuals were captured in a water trap method carried out at the same area above as a preliminary study (data not shown).
Because PPV is noncirculative and nonpersistent, transmission from an infected tree to a healthy tree must occur during a short time period. Therefore, the dominant vector changes depending on the types of aphid that are prevalent in a particular area. Three major vectors known in Eastern Europe are B. helichysi, H. pruni, and $P$. humuli whereas major vectors in Western Europe and North

Table 2. Results of a logistic regression analysis for the factors of survey year, survey area, survey month, and interactions among the three variables

\begin{tabular}{lccc}
\hline Factor & df & $\boldsymbol{G}$ & $\boldsymbol{P}$ \\
\hline Survey year & 1 & $5.38302 \mathrm{e}-6$ & 0.9981 \\
Survey area & 1 & $4.84864 \mathrm{e}-6$ & 0.9982 \\
Survey year $\times$ survey area & 1 & $1.69527 \mathrm{e}-6$ & 0.9990 \\
Survey month & 8 & 42.5094209 & $<0.0001^{\mathrm{a}}$ \\
Survey year $\times$ survey month & 8 & 4.40648246 & 0.8187 \\
Survey area $\times$ survey month & 8 & 8.63135991 & 0.3743 \\
Survey year $\times$ survey area $\times$ survey month & 8 & 16.4849223 & $0.0359^{\mathrm{a}}$ \\
\hline
\end{tabular}

a Significant difference.

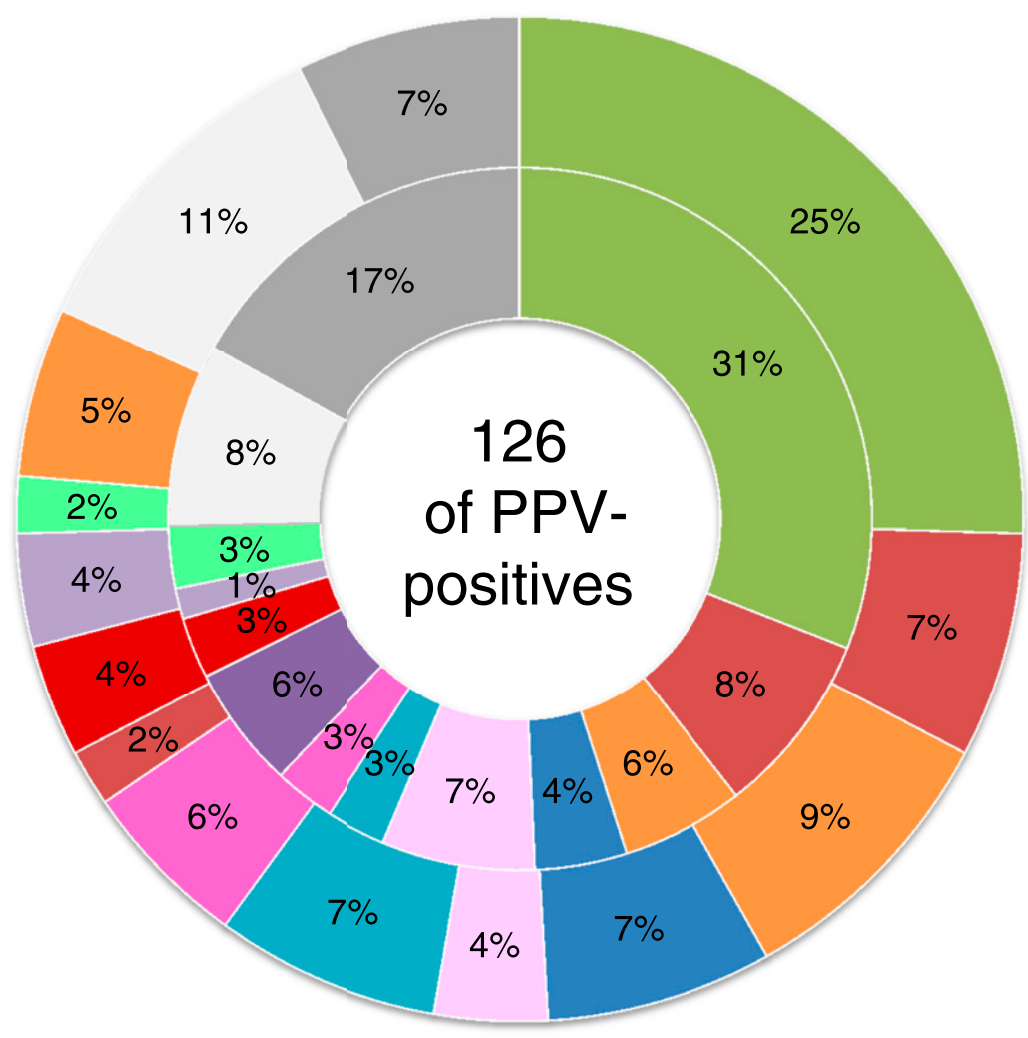

Aphis spiraecola

Tinocallis zelkowae

Phorodon humuli

Aphis fabae

Tuberocephalus momonis

Rhopalosiphum rufiabdominalis

minor species
Aphis gossypii

Aphis craccivora

Hyalopterus pruni

Shivaphis celti

Rhopalosiphum maidis

Aphis fukii

unknown

Fig. 3. Proportion of 126 alate aphid species showing Plum pox virus (PPV) positive reaction in a 2-year survey. The outside of the duplicate pie graph represents the high-density occurrence area (HDA) and the inside represents the PPV nonsurveyed area (NSA). 
America are A. spiraecola and M. persicae (Gildow et al. 2004). Transmission efficiency differs according to the biotype even among the same aphid species (Lupoli et al. 1992). Although H. pruni is a major vector in Eastern Europe, in contrast, a case of the species transmitting the virus has not yet been reported in Western Europe (Gildow et al. 2004). It is important to clarify the outbreak patterns of these major transmission vectors to prevent and eradicate infection. An investigation conducted in a peach orchard in Pennsylvania over a 2-year period revealed that outbreak peaks for A. spiraecola and $M$. persicae were in June to July and September to October, respectively (Wallis et al. 2005). An investigation conducted in a plum orchard over a 2-year period in Valencia, Spain, revealed that $A$. spiraecola and A. gossypii accounted for $80 \%$ of the 6,000 aphids characterized and that the outbreak peak was in May (Capote et al. 2008). These data illustrate that dominant aphid species and outbreak peaks vary in different geographic regions. In Japan, where the invasion of PPV was only recently confirmed, the aphid species that act as major vectors have yet to the identified.

The increased numbers of virus-positive insects in the fall are presumably attributable to an increased proportion of alate aphids sucking sap from green branches of Prunus mume, newly developed in summer, during the same period due to the presence of some aphid species that switch their hosts and return to $P$. mume or some other species that move away from $P$. mume to a secondary host before winter hibernation (Aoki 2000). In fact, some green branches of PPV-infected $P$. mume in the fall were tested positive for the virus (K. Maejima, personal communication). In addition, developing leaves in this period would be better for alate aphids that suck sap because the softness of those leaves is similar to that of leaves developed in the last spring, just before the summer. In contrast, a peak of the PPV-viruliferous aphids in the Mediterranean Sea area has been previously indicated to be in May (Cambra et al. 2004; Kaya et al. 2014). The cause of this peak in the Mediterranean Sea area may be that the alate aphids prefer the young, soft, developing leaves and shoots of $P$. salicina during early spring to those developing in late spring, just before the summer. In Japan, however, the aphids may prefer the green branches that characteristically grow in summer for $P$. mume, leading to the increased numbers of virus-positive insects in the fall. It is unclear what kinds of natural phenomenon cause such a big difference in whether a peak appears in late spring or fall; viruliferous aphids have occurred in both Japan and the Mediterranean Sea area thus far. In our experiments of aphid transmission, only aphids allowed to acquire PPV on young and soft leaves showing symptoms of PPV-infected $P$. mume could transmit the virus, whereas aphids failed to transmit PPV when old, hard infected leaves were used, even those showing indications of typical symptoms of the disease (data not shown). It is important to conduct further surveys in the field and clarify the ecological mechanism of PPV infection of plants because virus-positive insects are detected even after

Table 3. Results of a logistic regression analysis for the 2011 data, with factors of survey area, survey month, and interaction between the two variables

\begin{tabular}{lccc}
\hline Factor & df & $\boldsymbol{G}$ & $\boldsymbol{P}$ \\
\hline Survey area & 1 & $5.10488 \mathrm{e}-8$ & 0.9998 \\
Survey month & 6 & 19.6150276 & $0.0032^{\mathrm{a}}$ \\
Survey area $\times$ survey month & 6 & 8.79110311 & 0.1857 \\
\hline
\end{tabular}

a Significant difference.

Table 4. Results of a logistic regression analysis for the 2012 data, with factors of survey area, survey month, and interaction between the two variables

\begin{tabular}{lccc}
\hline Factor & df & $\boldsymbol{G}$ & $\boldsymbol{P}$ \\
\hline Survey area & 1 & 1.01103607 & 0.3147 \\
Survey month & 6 & 22.0686753 & $0.0012^{\mathrm{a}}$ \\
Survey area $\times$ survey month & 6 & 12.4479724 & 0.0527 \\
\hline
\end{tabular}

a Significant difference. infected trees are cut down, and species of trees that are infected other than $P$. mume may also play a part in the mechanism of virus transmission, especially for the increase of PPV-positive aphids in the fall.

A 2011

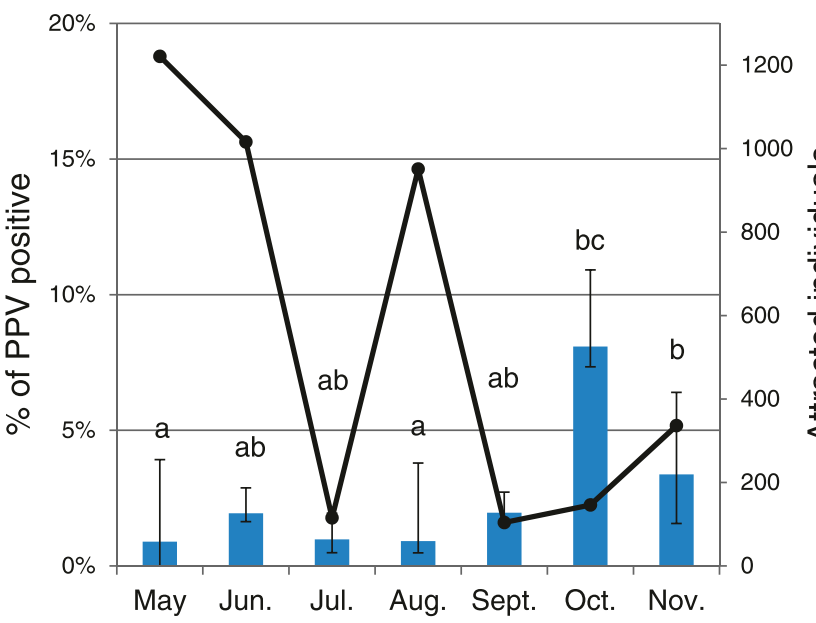

B 2012

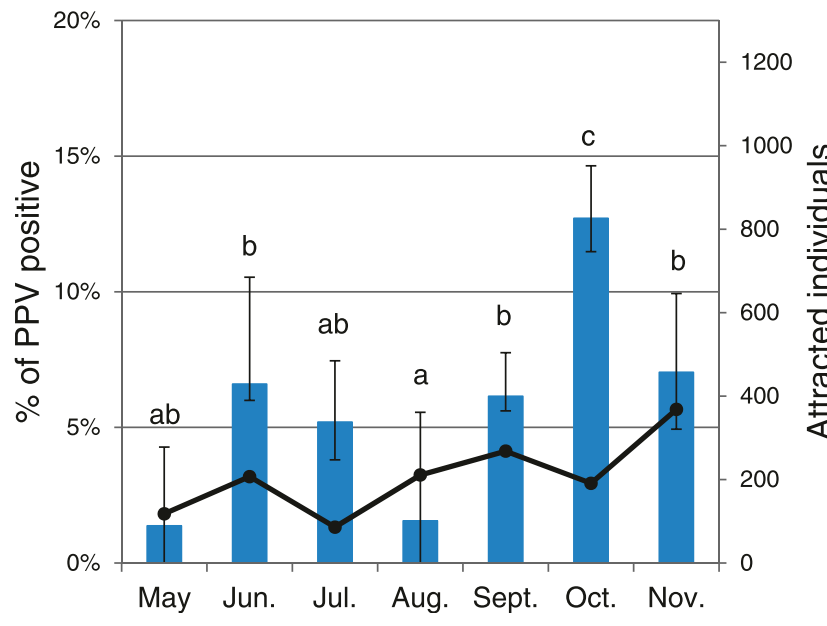

Fig. 4. Virus-positive rate of aphid species in the survey areas from each survey year: A, 2011 and B, 2012. Bar graph, virus-positive aphid ratio (\%, left axis); line graph, number of aphids trapped on yellow adhesive boards (right axis). Virus-positive rates for individual species were calculated based on the following equation.

$$
\mathrm{p} 1(\mathrm{n})=\mathrm{P}(\mathrm{n}) \times \frac{x 1(n)}{X(n)}
$$

Total viruliferous insect rate, $P(n)$; viruliferous insect rate of species, $p 1(n)$; total number of trapped individuals, $X(n)$; number of trapped individuals by species, $\mathrm{x} 1(\mathrm{n})$. Different letters indicate significant differences $(P<0.0001)$ between treatments after a G-test for contingency table (Bonferroni-Holm's corrected) followed by a Posthoc test. Bars on bar graphs represent standard errors.

Table 5. Plum pox virus (PPV) transmission by seven aphid species in laboratory assays

\begin{tabular}{|c|c|c|c|}
\hline Species & Inoculated & Infected & Transmission (\%) \\
\hline Myzus persicae & 45 & 11 & $24.4 \%$ \\
\hline Aphis spiraecola ${ }^{\mathrm{a}}$ & 61 & 8 & $13.1 \%$ \\
\hline M. mumecola & 41 & 5 & $12.2 \%$ \\
\hline A. craccivora $^{\mathrm{a}}$ & 19 & 1 & $5.3 \%$ \\
\hline A. gossypii ${ }^{\mathrm{a}}$ & 27 & 1 & $3.7 \%$ \\
\hline Rhopalosiphum maidis & 29 & 1 & $3.4 \%$ \\
\hline Melanaphis sacchari & 15 & 0 & $0.0 \%$ \\
\hline
\end{tabular}

${ }^{a}$ Species of aphids reported as PPV vectors. 
Although it is required to cut down infected trees to eradicate PPV in Japan, it is also important to decrease the population of the vector aphids that transmit PPV to prevent a further spread of the infection. In this study, application of insecticide three times during the spring in a customary manner made it possible to reduce the aphid numbers in HDA by approximately $50 \%$ compared with the level in NSA. Because the aphid occurrence peaks in early May, mid-June, and late August, insecticide should be sprayed 2 weeks prior to each peak for its effectiveness. Furthermore, based on the present virus test results, spraying insecticide in conjunction with the October and November peaks, when a high number of PPV-positive aphids were seen, is also desirable. Although insecticide treatments in the orchard may prevent the spreading of PPV, they may have very little effect on aphids passing through crops, which are the most efficient vectors of nonpersistent viruses such as PPV because they are not colonizers of the hosts of interest. In order to control PPV, it is necessary to carry out measures to reduce the population of alate aphids throughout the area.

Because Japan has a short history of dealing with PPV, many aspects of the disease remain to be elucidated. Therefore, it is recommended that surveys, including virus testing, be continued in local fields where PPV has occurred. In addition, in order to evaluate the risk of PPV spread more accurately, the transmissibility of aphid species suspected of being PPV carriers in local fields should be assessed and the risk analysis of infection should be conducted for trees in these areas. Through these studies, the spread of this viral infection is preventable by accumulating epidemiological knowledge, such as the ecological mechanism of PPV vector insects, and by identifying an optimum period for decrease in the numbers of aphid populations. We hope that our steady ongoing efforts will contribute to effective measures for the future eradication of PPV.

\section{Acknowledgments}

We thank T. Mitsunaga, NARO Agricultural Research Center (ARC), for his advice regarding statistical analysis; K. Kagawa, Utsunomiya University, for identifying the aphids; K. Kubota, Y. Tomitaka, and M. Kawabe, NARO-ARC, for their advice and feedback regarding this research and for the guidance they provided to carry out various experiments; Y. Matsumura, Y. Narita, and J. Sato, NARO-ARC, for their assistance in preparing biological samples and in laboratory work; and L. M. Knight, USDA-APHIS-PPQ, for critical reading of this manuscript. Part of this study was supported by a Grant-in-Aid for "The research project for utilizing advanced technologies in agriculture, forestry and fisheries" administered by the Ministry of Agriculture, Forestry, and Fisheries of Japan.

\section{Literature Cited}

Aoki, S. 2000. Life-cycle of Aphids. Pages 276-291 in: Biology of Aphids. H. Ishikawa, ed. University of Tokyo Press, Tokyo. (in Japanese)

Atanasoff, D. 1932. Plum pox. A new virus disease. Yearbook University of Sofa. Fac. Agric. Silvicult. 11:49-69.

Avinent, L., Hermoso, A., and Llacer, G. 1991. Comparison of traps for capture of alate aphids (Homoptera, Aphidinea) in apricot tree orchard. Agronomie 11: 613-618.

Cambra, M., Gorris, M. T., Capote, N., Asensio, M., Martinez, M. C., Bertolini, E., Collado, C., Hermoso de Mendoza, A., and Mataix, E. 2004. Epidemiology of Plum pox virus in Japanese Plums in Spain. Acta Hortic. 657:195-200.

Capote, N., Perez-Panades, J., Monzo, C., Carbonell, E., Urbaneja, A., Scorza, R., Ravelonandro, M., and Cambra, M. 2008. Assessment of the diversity and dynamics of Plum pox virus and aphid populations in transgenic European plums under Mediterranean conditions. Transgenic Res. 17:367-377.

Dallot, S., Labonne, G., Bueglin, M., Quiot-Douine, L., Quiot, J. B., and Candresse, T. 1998. Peculiar plum pox potyvirus D-populations are epidemic in peach trees. Acta Hortic. 472:355-365.

Fauquet, C. M., Mayo, M. A., Maniloff, J., Desselberger, U., and Ball, L. A. 2005. Virus Taxonomy, 8th rep. Elsevier Academic Press, San Diego, CA.
Fereres, A., and Moreno, A. 2009. Behavioural aspects influencing plant virus transmission by homopteran insects. Virus Res. 141:158-168.

Folmer, O., Black, M., Hoeh, W., Lutz, R., and Vrijenhoek, R. 1994. DNA primers for amplification of mitochondrial cytochrome $c$ oxidase subunit I from diverse metazoan invertebrates. Mol. Mar. Biol. Biotechnol. 3:294-299.

Foottit, R. G., Maw, H. E. L., von Dohlen, C. D., and Hebert, P. D. N. 2008. Species identification of aphids (Insecta: Hemiptera: Aphididae) through DNA barcodes. Mol. Ecol. Resour. 8:1189-1201.

Gildow, F., Damsteegt, V., Stone, A., Schneider, W., Luster, D., and Levy, L. 2004. Plum pox in North America: Identification of aphid vectors and a potential role for fruit in virus spread. Phytopathology 94:868-874.

Glasa, M., Marie-Jeanne, V., Labonne, G., Subr, A., Kudela, O., and Quiot, J.-B 2002. A natural population of recombinant Plum pox virus is viable and competitive under field conditions. Eur. J. Plant Pathol. 108:843-853.

Glasa, M., Prikhodko, Y., Predajňa, L., Nagyová, A., Shneyder, Y., Zhivaeva, T. Šubr, Z., Cambra, M., and Candresse, T. 2013. Characterization of sour cherry isolates of Plum pox virus from the Volga Basin in Russia reveals a new cherry strain of the virus. Phytopathology 103:972-979.

Goytia, E., Calvino, L., Garcia, B., Abella, D., and Moya, J. 2006. Production of Plum pox virus HC-Pro functionally active for aphid transmission in a transient expression system. J. Gen. Virol. 87:3413-3423.

Hebert, P., Cywinska, A., Ball, S., and de Waard, J. 2003. Biological identifications through DNA barcodes. Proc. Biol. Sci. 270:313-321.

Kaya, K., Gazel, M., Serçe, Ç. U., Elçi, E., Cengiz, F. C., Cambra, M., and Çağlayan, K. 2014. Potential vectors of Plum pox virus in the Eastern Mediterranean Region of Turkey. Entomol. Gen. 35:137-150.

Labonne, G., Yvon, M., Quiot, J. B., Avinent, L., and Llacer, G. 1995. Aphids as potential vectors of plum pox virus: Comparison of methods of testing and epidemiological consequences. Acta Hortic. 386:207-218.

Llacer, G., and Cambra, M. 1998. Thirteen years of Sharka disease in Valencia, Spain. Acta Hortic. 472:379-384.

Lupoli, R., Labonne, G., and Yvon, M. 1992. Variability in the transmission efficiency of potyviruses by different clones of Aphis gossypii. Entomol. Exp. Appl. 65:291-300.

Maejima, K., Hoshi, H., Hashimoto, M., Himeno, M., Kawanishi, T., Komatsu, K., Yamaji, Y., Hamamoto, H., and Namba, S. 2010. First report of Plum pox virus infecting Japanese apricot (Prunus mume Sieb. et Zucc.) in Japan. J. Gen. Plant Pathol. 76:229-231.

Mazyad, H. M., Nakhla, M. K., Abo-Elela, A., and El-Hammady, M. H. 1992. Occurrence of plum pox (sharka) virus on stone fruit trees in Egypt. Acta Hortic. 309:119-124

Olmos, A., Bertolini, E., Gil, M., and Cambra, M. 2005. Real-time assay for quantitative detection of non-persistently transmitted Plum pox virus RNA targets in single aphids. J. Virol. Methods 128:151-155.

Olmos, A., Cambra, M., Esteban, O., Gorris, M. T., and Terrada, E. 1999. New device and method for capture, reverse transcription and nested PCR in a single closed tube. Nucleic Acids Res. 27:1564-1565.

Reyes, F., Fiore, N., Reyes, M. A., Sepulveda, P., Paredes, V., and Prieto, H. 2003. Biological behavior and partial molecular characterization of six Chilean isolates of Plum pox virus. Plant Dis. 87:15-20.

Rosales, M., Hinrichsen, P., and Herrera, G. 1998. Molecular characterization of Plum pox virus isolated from apricots, plums, and peaches in Chile. Acta Hortic. 472:401-405.

Roy, S., and Smith, I. M. 1994. Plum pox situation in Europe. Eur. Plant Prot. Organ. (EPPO). Bull. 24:515-523.

Tsuda, S., and Sano, T. 2014. Threats to Japanese agriculture from newly emerged plant viruses and viroids. J. Gen. Plant Pathol. 80:2-14

Uzest, M., Gargani, D., Drucker, M., Hebrard, E., Garzo, E., Candresse, T., Fereres, A., and Blanc, S. 2007. A protein key to plant virus transmission at the tip of the insect vector stylet. Proc. Natl. Acad. Sci. USA 104:1795917964.

Wallis, C. M., Fleischer, S. J., Luster, D., and Gildow, F. E. 2005. Aphid (Hemiptera: Aphididae) species composition and potential aphid vectors of Plum pox virus in Pennsylvania peach orchards. J. Econ. Entomol. 98: 1441-1450.

Wang, R. Y., Powell, G., Hardie, J., and Pirone, P. T. 1998. Role of helper component in vector-specific transmission of potyvirus. J. Gen. Virol. 79: 1519-1524.

Wetzel, T., Candresse, T., Macquaire, G., Ravelonandro, M., and Dunez, J. 1992. A highly sensitive immunocapture polymerase chain reaction method for Plum pox potyvirus detection. J. Virol. Methods 39:27-37. 